\title{
Can Pigouvian taxation internalize the social cost of platinum-group element emissions?
}

\author{
Danuse Nerudova ${ }^{1}$, Marian Dobranschi ${ }^{1}$ and Vojtech Adam ${ }^{2,3, *}$ \\ ${ }^{1}$ Department of Accounting and Taxes, and \\ ${ }^{2}$ Department of Chemistry and Biochemistry, Mendel University in Brno, Zemedelska 1, CZ-613 00 Brno, Czech Republic \\ ${ }^{3}$ Central European Institute of Technology, Brno University of Technology, Technicka 3058/10, CZ-616 00 Brno, Czech Republic
}

\begin{abstract}
Here we discuss the suitability of a Pigouvian tax on platinum-group element (PGE) emissions. Based on Pigou's theory, we develop a proposal for a viable and efficient tax to curb the negative effects of PGE emissions. The proposed emissions-impacting tax derives from an analysis of the fundamental rationale underlying Pigou's theory of internalizing the social cost of environmental externalities. The results indicate that sustainability of PGE taxation depends on the capacity of the tax to internalize the external costs of pollution and to enhance transition to environment-friendly technologies.
\end{abstract}

Keywords: Environmental externalities, external costs, platinum-group elements, social cost, taxation.

CAR engines are currently a major source of environmental pollution. Automobile manufacturers have installed catalytic converters in cars to reduce the exhaust's gas emissions of carbon monoxide ( $\mathrm{CO}$ ), unburned or partially burned hydrocarbons (HC) and nitrogen oxides $\left(\mathrm{NO}_{x}\right)$. Platinum-group elements (PGEs) are the main active components of catalytic converters, but due to high temperature and engine vibration, the interaction between exhaust gases and wash coat of the catalysts releases a significant amount of PGE emissions into the environment. König et al. ${ }^{1}$ assert that at least $10 \%$ of all PGE emissions is water-soluble, while Ravindra et $a l^{2}$ emphasize that the metallic form of PGEs does not pose an immediate threat as it is inert in biological reactions. However, certain platinum salts are highly potent allergens and sensitizers. PGE salts have been linked to serious human health problems, including nausea, increased spontaneous abortions and dermatitis. PGE emissions are released in particulate form and a significant percentage is water-soluble, which can cause environmental damage to air, soil and water. Moreover, these emissions have been traced in plants and animals entering the food chain.

\section{Sources of PGEs}

The last decade has seen the significant increase in the concentration of platinum metals in environmental sam-

*For correspondence. (e-mail: vojtech.adam@mendelu.cz) ples such as soil, road dust, surface water, sediments and plants $^{3-8}$. The main source of these PGEs is automotive emission catalysts, which use the unique catalytic properties of PGEs. Other sources include medicine and jewellery ${ }^{2,9-14}$.

\section{PGEs and cells}

PGEs are released in various forms, including nanoparticles, but their effects on different cell types are not yet fully understood. PGEs have been found to trigger toxic effects in primary keratinocytes by decreasing cell metabolism, but these changes have not been found to affect cell viability or migration. Furthermore, smaller particles, made from PGEs, exhibited greater deleterious effect on DNA stability than their larger counterparts ${ }^{15}$.

\section{Influence of PGEs on plants}

Plants are the first link in the food chain. The intake of heavy metals by the soil is mainly due to the presence of complexing agents (organic acids) that are secreted by plants. Data suggest that plants absorb PGEs (mainly palladium) from the soil through their roots, after which PGEs bind to biologically active substances that are rich in sulphur ${ }^{16-20}$. PGE accumulation primarily occurs in the vegetative parts of plants, decreasing in the following order: root $>$ stem $>$ leaf. It has also been observed that larger quantities of PGEs accumulate on the surface tissues of underground plant parts ${ }^{21}$.

\section{Influence of PGEs on animals}

Numerous published studies describe the adverse effects of platinum on some important biochemical pathways in animals, mostly mammalian cells ${ }^{22}$. However, the potential effects of environmental exposure to PGE are less understood. Limited data currently exist regarding the subclinical effects on animals caused by chronic low-dose exposure to PGEs, as most of the available information on PGE toxicity relates to platinum and the use of platinum-containing substances in chemotherapy ${ }^{23}$. Although environmental levels of PGEs are generally lower 
than those found in people who are occupationally exposed to these metals, studies indicate that ambient exposure can elicit the effects on a subclinical level, which is not readily detected among the general population $^{24}$.

The contribution of this article is two-fold. First, it addresses the need for fiscal instruments to internalize the negative externalities of PGE emissions. Pigouvian taxation represents an appropriate instrument to reduce the social costs of PGE emissions. Second, the article assesses the necessary adjustments of Pigouvian tax rates on PGE emissions, taking into consideration the interaction between social costs and social benefits. To the best of our knowledge, there are no earlier studies examining the possibilities of internalizing the negative externalities of PGE emissions through Pigouvian taxation. The peculiar external costs of PGE emissions make this a complex endeavour. The negative externalities of PGE emissions are undeniably harmful to the environment and public health. Therefore, a tax is necessary to curb these negative effects. However, PGE emissions are produced by an essential sector, viz. transportation, which provides social benefits as well as private gains.

\section{Negative environmental externalities}

This study excludes extreme pollution-mitigation measures, such as the cessation of all polluting activities for the sake of environmental protection or the complete avoidance of nonrenewable resource depletion, as such measures are impracticable responses to what is essentially a vital dependence on conventional technologies. Alternatively, the gradual replacement of conventional technologies with alternative green technologies represents a more realistic solution to negative externalities. Empirical studies analysing the internalization of negative externalities are grounded in comparisons between marginal social cost and marginal private cost. Centeme$\mathrm{ri}^{25}$ provides a useful perspective in this respect, concluding that the concept of marginal economics does not apply to environmental damages due to the complexity of natural systems. Moreover, her analysis of environmental externalities asserts that determining the exact social cost of environmental damages is a complex and nearimpossible process. Centemeri ${ }^{25}$ instead argues that not all objectives are tradable, noting that people are unable, or simply refuse, to put an exact price on social relationships (i.e. relationships with the environment).

According to $\mathrm{Kapp}^{26}$, market failure is not responsible for negative externalities being viewed as environmental externalities. Rather, it is the failure of the market as a cognitive, moral and material framework for addressing the environment. Papandreou ${ }^{27}$ similarly argues that the non-existence of a market that is too expensive or that is impossible to implement may not signal inefficiency, but represents the best possible result. It is important to address this debate, particularly considering the 'nonexistence' of a market for externalities such as clean air or a healthy environment, since these are costs (losses), rather than goods, which provide a pure public good that cannot be divided and sold as a private product.

Environmental externalities are the free-rider problem of the irrational and uncontrolled consumption of a clean environment. Pollution becomes the cost of free riding when production and consumption use conventional, fossil fuel-based technologies that damage the environment.

This article thus analyses the capacity of environmental taxation to eliminate pollution associated with PGE emissions. This objective is achieved through a theoretical analysis of the rationale underlying environmental taxation, using primary studies that both reinforce and refute Pigou's theory. The fallacies behind Pigou's rationale are highlighted, as are the misleading results of a corrective tax that treats private and social costs differently. In so doing, this article demonstrates that Pigouvian taxation must be adjusted in order for it to be efficient. This approach highlights the useful features of Pigouvian tax and the ways in which an additional mechanism could enhance the efficiency of a tax on negative externalities.

\section{Literature review}

The negative externalities of PGE emissions can be defined as a form of market failure that emerges whenever free market output is greater or smaller than its socially optimum level of output. According to Galbraith ${ }^{28}$, the problem of negative externalities is the result of a limited environment in which people's needs are, to some extent, unlimited. Damaging the environment, through pollutant activities that range from toxic gas emissions to excessive deforestation, invokes a global cost on people's own space of existence. Cheung ${ }^{29}$ similarly stresses that externalities arise from economic activities performed by an individual or firm, which impact a third party not involved in the transaction.

$\operatorname{Hardin}^{30}$ uses the tragedy of commons to describe the difficulty of assessing the links between costs and benefits, and between actions and effects. Taking the aggregate private and social costs of environmental externalities into consideration, the author notes that when a product provides consumers with private benefits that are greater than the social benefits of its consumption, then the resulting spillover costs are borne by society as a whole.

Just as the free market will produce either sub-optimal level or supra-optimal level of goods and services, Pigou's basic classification of negative externalities in consumption tends to define consumers' private or individual benefits from a social or collective (or global) perspective. Furthermore, it treats them separately, without 
attempting to aggregate them. In other words, economic theorists tend to ignore significant interdependencies between private and social costs and benefits.

The literature proposes different methods to reduce and eliminate negative externalities, which can be broadly grouped into market-based instruments (e.g. emission taxes) and cap-and-trade systems.

The mainstream approach to reducing negative externalities is to impose a price on the external costs of pollution. Pigou ${ }^{31}$ states that a tax should be imposed that is equal to the marginal social damage created, which will internalize the external cost of a polluter into its private costs. Since Pigou's contribution has been applied to tackle market failure, adherents to this theory offer useful amendments to a Pigouvian understanding of externalities.

Sandmo $^{32}$ furthers Pigou's theory by analysing the second-best optimal tax structures and by devising the term 'additive property'. He reinforces that Pigouvian taxes can be useful if they are inserted into a more comprehensive system of indirect taxation, where environmental taxes are implemented in the context of an existing system of taxation. Sandmo ${ }^{32}$ argues that, since the consumer's income and relative prices will differ over time, their social damage will also vary. As such, the optimal tax on commodities that create externalities should be based on a weighted average of two terms: the marginal social damage of that particular commodity and the inverse elasticity of demand. If one assumes that the existent tax system is optimal, in that it does not create any kind of distributional negative effects, then a new tax, like a carbon tax, would disturb and result in welfare loss. This is due its distortionary effects, including a regressive effect on low-income households. Sandmo ${ }^{32}$ questions the applicability of double dividend theory in the context of green taxes by outlining the ways in which its occurrence depends on the initial state of the tax system and on the structure of demand, especially regarding cross-price elasticity of the markets for clean and dirty goods. The author further demonstrates the efficacy of environmental taxes by stressing the fact that tax on 'dirty goods' should be enforced by imposing additional regulations on harmful and pollutant goods.

Addressing the issue of negative environmental externalities, Meade ${ }^{33}$ asserts that the taxes or subsidies required to either promote environmental protection or to discourage unfavourable pollution represent net additions to society's general fiscal burden. Both Sandmo ${ }^{32}$ and Meade $^{33}$ thus conclude that the implementation of environmental taxation would increase excess burden on the existing tax system.

Bovenberg and Goulder ${ }^{34}$ argue that the optimal environmental tax rate in a pre-existent distortionary tax system should be lower than the rate proposed by the Pigouvian theory. This notion is supported by critics, including Cremer et al. ${ }^{35}$, who state that an optimal com- modity tax, which targets the production and consumption creating negative externalities, is not same as the Pigouvian tax. Cremer et $a l^{35}$ stress that the environmental tax rate is decreased by Sandmo's ${ }^{32}$ additional property of corrective taxation, which tends to distort market prices. Following Sandmo's ${ }^{32}$ proposal, Oates ${ }^{36}$ demonstrates that carbon taxes, as well as reducing the level of polluting activities, also provide important incentives for research and development into new abatement technologies.

Some economists, however, question the applicability of the Pigouvian rationale. Jaeger ${ }^{37}$, for example, studied environmental taxation in a second-best setting, concluding that the benefits of revenue recycling increase marginal social benefits; thus, the environmental tax rate should be higher than the Pigouvian rate. Christiansen and Smith $^{38}$ suggest a less-sophisticated method for decreasing the negative externalities of pollution, which can be achieved by implementing an environmental tax that is based on proxies rather than a tax on carbon emissions. The authors argue that introduction of a mixed policy would achieve more efficient pollution abatement, with environmental taxes supplemented and accompanied by a command-and-control policy.

Baumol $^{39}$ proposes an alternative assessment of Pigouvian taxation, acknowledging weaknesses in the Pigouvian rationale and proposing an environmental tax based on a minimum set of standards. This approach aims to maintain pollution between certain socially acceptable limits.

Sandmo $^{32}$, Eskeland ${ }^{40}$, and Fullerton and Wolverton ${ }^{41}$ emphasize the notion of a presumptive Pigouvian tax, represented by taxes that exploit the presumed relationship between the product that is taxed and pollution that needs to be regulated. They argue that indirect taxes that have a corrective effect on harmful consumption (e.g. excise duty on fossil fuels) should be accompanied by subsidies to enhance environmental protection. Such a mix of instruments could offset weakness and steer consumer behaviour towards environment-friendly consumption. Bruha and Scasny ${ }^{42}$ assert that, in addition to reducing pollution, Pigouvian taxes could also be employed to decrease the overall tax burden of distortionary taxes, through revenue recycling. Cuervo and $\mathrm{Ved}^{43}$ similarly highlight the need for Pigouvian rational adjustment. Since it is impossible to determine the exact social cost of pollution, an environmental tax should aim to maintain pollution levels below a socially acceptable threshold.

One of the strongest refutations of the Pigouvian rationale is the suggestion of Coase $^{44}$ that the issue of negative externalities could be resolved through bargaining between the polluter and the bearer of external costs. Thus, in a setting where rights are pre-established, external costs could be internalized through negotiation between affected parties. Coase' ${ }^{44}$ approach towards the 
internalization of negative externalities can be applied to a setting in which transaction costs are zero, but this recommendation is questionable in the context of environmental externalities since transaction costs are exorbitant. Libecap $^{45}$ dismisses Coase's theory on negative externalities by highlighting high transaction costs and uncertainty, coupled with lack of information and property rights.

The contribution of Coase $^{44}$ to the field reveals an important aspect of the issue of negative externalities, as external costs stem from the lack of property rights assignment. Lewin ${ }^{46}$ describes environmental tax as a form of compensation, since social costs are deemed to be opportunity costs. Therefore, according to Lewin ${ }^{46}$, Pigouvian taxation should be imposed on the principle of strict liability, where a polluter which causes the harm to the third party should be compensated for the external costs produced.

Färe et $a l .{ }^{47}$ highlight the ways in which the literature of productivity measurement tends to ignore the provision of undesirable output (e.g. pollution), when considering the production of desirable goods. Their study proposes a performance measure in which 'good' and 'bad' are treated asymmetrically, using shadow prices and a distance-based function. The rationale of the directional output-oriented distance function, initially proposed by Shephard $^{48}$, is applicable in the context of pollution abatement because it considers companies with one 'good' output $=y 1$ (e.g. transportation) and one associated 'bad' output $=y 2$, which includes PGE emissions.

The directional distance function establishes a relationship between inputs and outputs, where production technology is represented by a composed output set $=P(x)$. The directional distance function, which is outputoriented, equals

$$
D_{0}^{\rightarrow}\left(x, y, g_{\mathrm{y}}\right)=\max \left\{\beta: y+\beta g_{\mathrm{y}} \in P(x)\right\}
$$

In eq. (1), $g_{\mathrm{y}}$ represents the directional vector and $g_{\mathrm{y}}=\left(y_{1}, y_{2}\right)$, according to Matsushita and Asano ${ }^{49}$. In order to derive the revenue function, the equation proposed by Hudgins and Primont ${ }^{50}$ is used

$$
R(x, p, q)=\max y\left\{p y_{1}-q y_{2}: y \in P(x)\right\} .
$$

Equation (2) can be rewritten in distance function terms, as in Matsushita and Asano ${ }^{49}$

$$
R(x, p, q)=\max y\left\{p y_{1}-q y_{2}: D_{0}^{\rightarrow}\left(x, y, g_{\mathrm{y}}\right) \geq 0\right\} .
$$

The Lagrangian function for eq. (3) is

$$
L=p y_{1}-q y_{2}+\lambda D_{0}^{\rightarrow}\left(x, y, g_{\mathrm{y}}\right) .
$$

The shadow price of PGE emissions $(q)$ of $y_{2}$ is

$$
q=-p *\left[\frac{\nabla y_{2} D_{0}\left(x, y, g_{\mathrm{y}}\right)}{\nabla y_{1} D_{0}^{\rightarrow}\left(x, y, g_{\mathrm{y}}\right)}\right]
$$

According to eq. (5), $q$ or the shadow price of PGE emissions can be interpreted as the marginal abatement cost of PGE. $q$ can be determined by multiplying the price of 'good' output (e.g. transportation) with the marginal rate of transformation between the good output and PGE emissions.

The Pigouvian tax can play the role of shadow price for undesirable 'bad' outputs that inadvertently result from the production process. Therefore, the directional distance function approach can use the pre-established Pigouvian tax rate for undesirable outputs (PGE emissions or other pollutants) in order to calculate the performance of the production process. Moreover, the distance function approach proposed by Shephard ${ }^{48}$ and later expanded by Färe et al. ${ }^{51}$ can be used to calculate the Pigouvian tax rate needed to reduce undesirable outputs for specific industries.

Several studies assess the applicability and feasibility of Pigouvian taxation, both theoretically and empirically. The Pigouvian taxation is assessed theoretically, for instance, by Ekins et al. ${ }^{52}$ in the context of environmental tax reform. They evaluate the potential of Pigouvian levies to shift taxation to harmful outputs and away from inputs such as labour, concluding that environmental tax reform can decrease pollution and increase employment, without affecting the level of tax revenues collected by the government. Jones et al. ${ }^{53}$ address the fiscal implications of pollution-abatement policies. They stress that the field still lacks a clear response regarding comparison of the short-term costs of pollution mitigation and its longterm benefits. Gahvari ${ }^{54}$ notes that the Pigouvian taxation should not be interpreted as a purely environmental tax that focuses exclusively on environmental protection issues. Instead, it should consider interactions between consumption (as a proxy for demand), labour supplies and the environment, in order to assess the trade-offs between costs and benefits. In their analysis of the feasibility of a carbon footprint tax, McAusland and Najjar ${ }^{55}$ argue that a pure carbon footprint tax is unfeasible, due to the costs involved in measuring each individual carbon footprint. Instead, they propose a hybrid carbon footprint tax, in which firms calculate the carbon footprint for each unit of their output and include the tax in the final price paid by end consumers. Tideman and Plassmann ${ }^{56}$ suggest that marginal cost pricing principles should be taken into account when the Pigouvian taxes are designed. This recommendation arises from the rationale that each polluter should bear a tax burden equal to the marginal social cost of each unit of the harmful goods produced and consumed. Conversely, Hoffmann et al. ${ }^{57}$ analyse the 
efficiency of Pigouvian taxation from a firm-level perspective, concluding that the Pigouvian taxes should only be implemented when associated with grants that are tied to loans. This, they argue, would improve both resource allocation and general well-being.

The field also engages in empirical analysis of Pigouvian taxation efficiency and feasibility. Particularly relevant research was recently published by De Borger and Glazer $^{58}$, which assesses the challenges of imposing a road pricing toll, particularly in the context of future taxpayers' high- and low-loss aversion. Matsumura and Yamgishi ${ }^{59}$ analyse the impact of Pigouvian taxes in different settings, including in terms of both perfect and imperfect competition. They conclude that the Pigouvian taxes are generally more useful in imperfect competition settings, as they can improve social welfare. Another interesting empirical analysis of Pigouvian tax effectiveness was conducted by Lanz et al. ${ }^{60}$. This study focuses on the behavioural responses of individuals when an external intervention (e.g. Pigouvian taxes) is implemented to correct the consumption of harmful goods. Lanz et al. ${ }^{60}$ demonstrate that introducting Pigouvian taxes to reduce negative externalities (e.g. pollution) can actually have the opposite effect on demand for harmful goods, such as fossil fuels. Therefore, the authors recommend an adjusted regulatory intervention, where the Pigouvian taxes are higher than the socially optimum level, in order to offset negative behavioural responses. Another empirical paper concerns the spillovers of Pigouvian taxation on $\mathrm{CO}_{2}$ emissions. Leinert et al. ${ }^{61}$ state that, even if $\mathrm{CO}_{2}$ taxation in Ireland successfully reduced $\mathrm{CO}_{2}$ emissions, consumers would switch to substitutes such as diesel cars, which introduces the issue of $\mathrm{NO}_{x}$ emission increases due to car fleet dieselization. The impact of air pollution on population health is the subject of research by Kubatko and Kubatko ${ }^{62}$. They propose a Pigouvian tax on air pollution that is between seven and 13 times higher than the present air pollution taxation, in order to fully internalize current expenditure on health issues that are triggered by air pollution.

\section{Myopic approach to the internalization of social costs}

Buchanan and Stubblebine ${ }^{63}$ assess the Pigouvian rationale in the context of Pareto optimality. Taking the Pareto optimality into consideration, when a polluter is charged with a tax because it creates a harm on a third party, its private equilibrium is affected through the diseconomy created by tax imposition. Buchanan and Stubblebine ${ }^{63}$ thus recommend a tax on both parties (i.e. the polluter and the third party) so that the Pareto optimality is restored and neither party benefits at the cost of the other. Moreover, assuming that the external costs of pollution also affect the polluter, imposing an environmental tax on the polluter induces a double cost, which reinforces the assertions of Buchanan and Stubblebine ${ }^{63}$.

A combination of tax and compensation is an appropriate solution in this context. This would restore the Pareto optimality, reduce the polluter's costs, improve environmental protection, and also increase third-party benefits, who indirectly benefit from lower external costs. Figure 1 presents the classical treatment of negative externalities in a first-best scenario, following Pigou's rationale. Polluter $A$ creating external costs that are subsequently inflicted on third party $B$ results in a difference between the marginal private cost (MPC) and the marginal social cost (MSC). To internalize the external costs of $A$ 's activity, Pigou proposes a tax $\left(t_{x}\right)$ equal to the damage inflicted on $B$, which would reflect the MSC, where $\mathrm{MSC}=\mathrm{MPC}+t_{x}$. The difference between MPC and MSC (represented by the triangle $A B C$ ) is the welfare loss from $A$ 's activity before the tax is enacted. By increasing the price from $P_{0}$ to $P_{0}+t_{x}$ through the negative externality tax, the output quantity of $A$ 's activity will decrease from $Q_{0}$ to $Q_{1}$, reaching the social optimum. Negative externalities and social cost are difficulties arising from the economic activities of an individual or firm, in terms of consumption or production, which generate an effect (i.e. externality), be it beneficial or detrimental, on some other individual or firm that is not party to the original activity. The private cost of the activity, which, together with associated private benefits, determines the scale on which it operates, will then diverge from 'social' costs and benefits, which include the costs and benefits to others. In the context of environmental externalities (which are seen as negative), it is generally accepted that social costs are also borne by the polluter itself, so a perfect Pigou tax (that calculates the exact social cost imposed on third parties) treats the polluter as a net beneficiary of its activities. In this situation, the diseconomy (or cost of tax) will double its impact on losses. Despite criticisms expounded by detractors of the Pigouvian theory, future environmental taxation should adopt the proposed adjustments to the Pigouvian rationale. Consequently, the environmental tax rate imposed on pollution should be adjusted (i.e. decreased) by the corresponding social benefits associated with economic activities that cause pollution. This rationale intends to reduce the distortionary costs of environmental taxation below that of the social costs of pollution. Adjustments to the Pigouvian-based environmental tax rate engage with the aggregate flow of private and social costs and benefits to both polluters and third parties. This is illustrated by an example of a transport company. Assuming that the company only uses dieselpowered trucks with diesel particulate filters, the PGE emissions represent negative externalities that need to be addressed. In this example it is also assumed that the transport company operates in a closed economy. As such, PGE emissions pollute the soil and thus affect the quality of food products consumed by the polluter (i.e. 


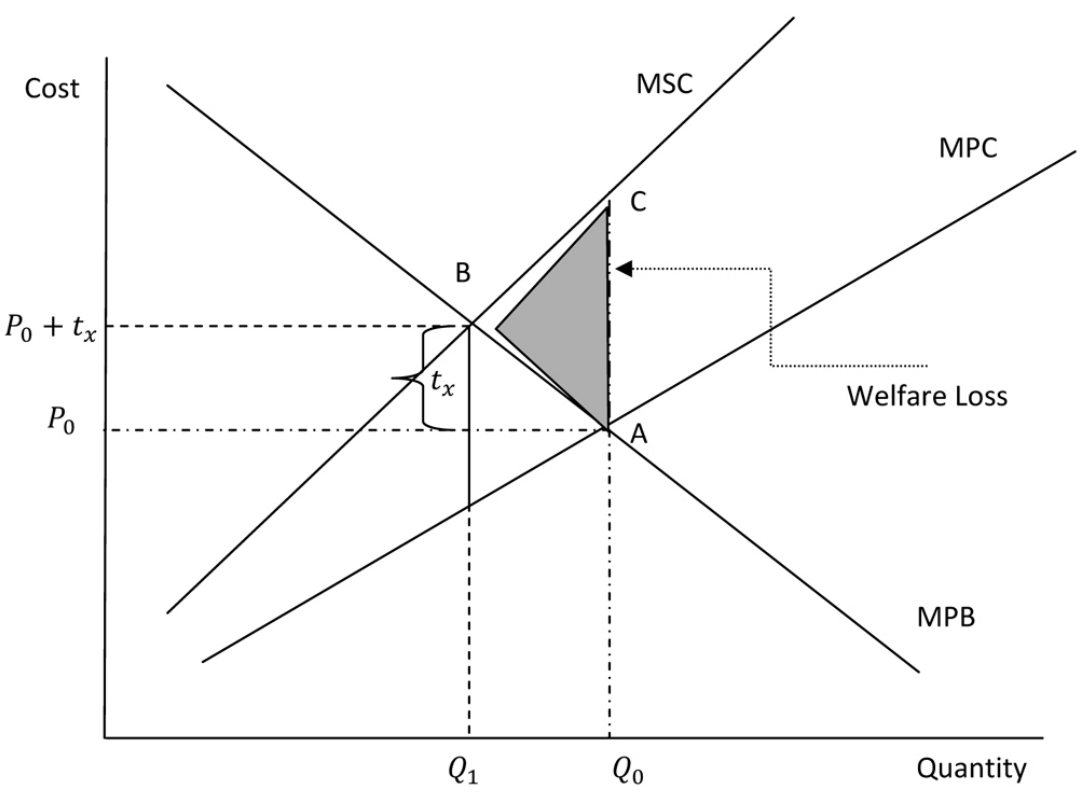

Figure 1. Pigouvian environmental tax on negative externalities.

employees of the transport company), as well as by third parties (i.e. clients of the transport company). In this situation, the social cost of PGE emissions is directly linked to welfare loss, relative to third parties. The third parties can be represented by soil and water polluted with toxic PGE metals. Further, PGE particles pose a serious health risk to land near the roads that is used for crop or livestock production. However, it is also clear that the polluter's transportation of goods and rendering services also creates both private and social benefits and costs. A tax on negative externalities must subsequently engage with a complex set of interrelated costs, and a tax rate must be established that considers the combination of private and social benefits, not solely the combination of costs. The mainstream solution would require an environmental tax on PGE emissions in order to internalize the external costs of pollution (e.g. $\mathrm{MSC}=\mathrm{MPC}+t_{x}$ ). However, the transport of goods and services also has social benefits for third parties. In this case, these social benefits should also be included in the equation, which would adjust the social costs and result in a lower environmental tax rate.

Assuming that the external costs from the transport company are greater than the external benefits of transportation of goods, when the MSB curve is added to Figure 2, the welfare loss caused by the polluting activity of the transport company (represented by the triangle $A^{\prime} B C^{\prime}$ ) will be smaller than in the previous scenario (see Figure 1, triangle $A B C$ ), which excludes the external benefits. Since the welfare loss caused by harmful transport activity is reduced by the external benefits created by its consumption, the environmental tax rate on PGE emissions should be lower than the Pigouvian tax rate. The tax rate $t_{x}$ should be adjusted by the amount of external benefits to $t_{x}^{\prime}$. This rather simple example of an economic activity that generates external costs (i.e. soil polluted with PGEs) requires a certain amount of adjustments, because dieselpowered transportation renders both private and social benefits and costs. Therefore, the optimal rate of environmental tax takes into account the private and social benefits of an activity, not merely its external costs. Moreover, the use of Pigouvian taxes can have a positive impact on emerging economies. Following the traditional rule of taxing outputs and not inputs, emerging economies can shift from taxing labour to a system of indirect taxation that taxes outputs (e.g. Pigouvian taxation on harmful goods and services). Therefore, adopting the Pigouvian taxation can lead to environmental protection (e.g. decreasing PGE emissions) and reduction of tax burdens on labour (e.g. increasing employment). The double dividend provided by the Pigouvian taxation is the focus of research by Nerudova and Dobranschi ${ }^{64}$.

Ramsey ${ }^{65}$ has devised the inverse elasticity rule to improve the efficiency of taxation in terms of revenues that do not produce significant distortions of demand and supply. He suggests that, in order to maintain a steady stream of revenue, taxes should be directed towards those commodities with an inelastic price elasticity in terms of demand. Ramsey's ${ }^{65}$ assessment demonstrates that environmental taxes on fossil fuels could become a robust source of tax revenues, since fossil fuels are necessities and taxation will have a small impact on their consumption.

The design of an environmental tax should be consistent with the fundamental rules of taxation, the first of which is that a tax should produce an observable 


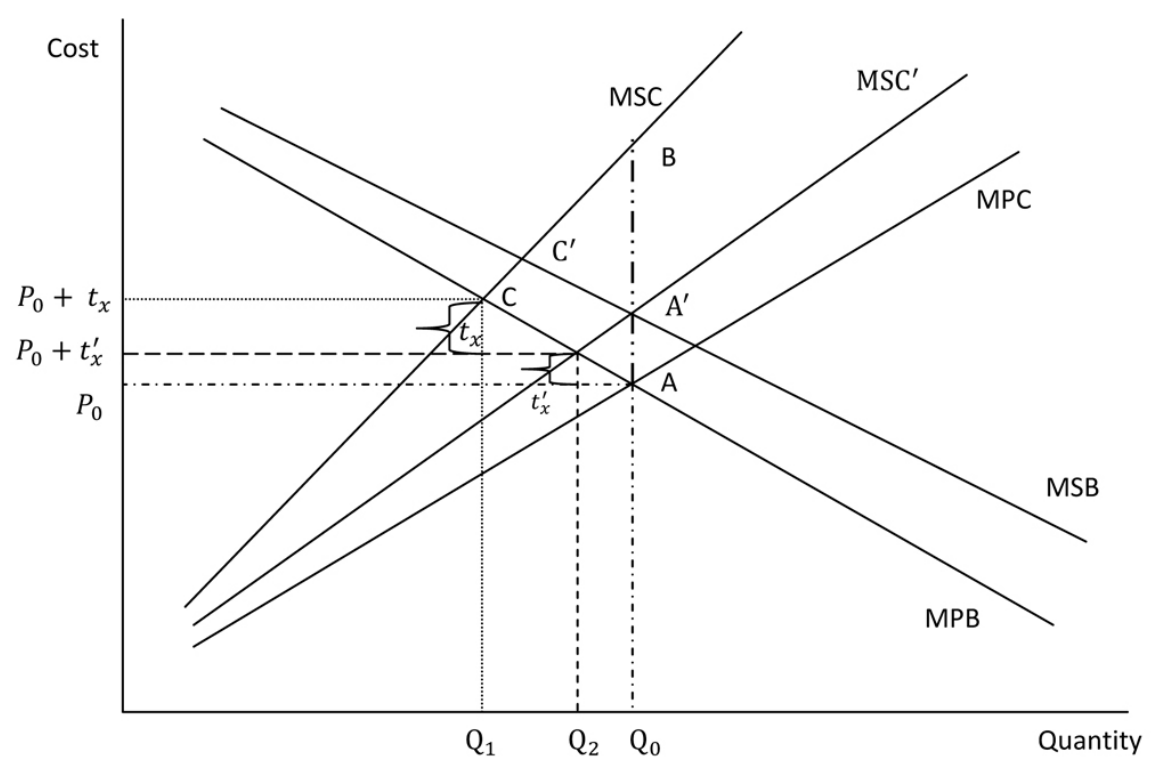

Figure 2. Adjusted Pigouvian tax rate on environmental emissions.

economic outcome. In this case, a tax on the consumption of energy or the fuel used to produce energy creates a clear economic outcome. The second rule is that an environmental tax should be neutral. The fundamental purpose of an environmental tax is not to collect revenues for the public budget, but to improve environmental protection. Compared with other measures used to tackle environmental externalities, such as cap-and-trade systems, environmental taxation offers the advantage of revenue recycling. Finally, an environmental tax should not amplify the distortions created by the existing fiscal system. Rather, a tax-and-compensation system has two goals: protecting the environment and reducing the distortions caused by direct taxes, such as taxes on capital and labour.

The excise duty element of a Pigouvian tax further demonstrates that the PGE emission tax rate should be lower than the Pigouvian rate. Excise duties are imposed in order to lower the consumption of harmful goods that damage individual and societal welfare, such as alcohol, tobacco, coffee, gasoline and diesel fuel. Regarding the impact of excise duties on the price paid by the final consumer, Kenkel ${ }^{66}$ reveals that the tax burden of an excise duty on alcoholic beverages in Alaska was over-shifted to the final consumer. Contrary to tax incidence theory, which assumes that the tax burden is borne equally by sellers and buyers, the tax burden of excise duties is usually forward shifted and thus exceeds the one-for-one rule. Accordingly, if tax on spirits is increased by one monetary unit, the price response to this tax hike will exceed one unit. Bergman and Hansen analyse the passthrough of excise duties on beverages in Denmark, concluding that taxes were more than fully passed on to the final consumer. Although their results are partially con- sistent with those of Kenkel ${ }^{66}$, Bergman and Hansen dismiss the notion of a uniform effect of excise duties on prices. In contrast, they outline certain cases where the tax burden was forward-shifted by less than or close to a $1: 1$ ratio. This phenomenon can be explained in terms of market competitiveness. Specifically, in a perfectly competitive market with constant marginal costs, taxes are assumed to be shifted at a one-for-one rate in order to determine the final price. In the Alaska study, Kenkel ${ }^{66}$ concludes that low-price retailers with numerous suppliers of alcoholic beverages set a low baseline price in order to attract clients. However, when tax rates increased, these retailers used the tax increase as a pretext to over-shift the burden to the final price and thus artificially inflate the charge to the consumer. Therefore, a perfectly competitive market, in which sellers are pricetakers, provides some leeway to increase the price without losing customers. In contrast, in a market with few sellers (such as a monopoly or oligopoly), the suppliers are the price-makers. As such, there is little room to increase prices following a tax increase, as the prices are already high. This theoretical contribution of the present study arises from the dual approach to social costs and social benefits, when the Pigouvian taxes are designed. It highlights the tendency of the literature to isolate social costs and treat them as separate from social benefits, when the Pigouvian tax rates are calculated. Therefore, an integrated approach based on the interrelation between social costs and social benefits is suggested in order to adjust the Pigouvian tax rate.

The conclusions of this study are based on the interrelationship between social costs and social benefits of economic activity that is pollution-generating but 


\section{RESEARCH ARTICLES}

nonetheless valuable, as well as the impact of social cost of this activity on the polluter itself, and the forward over-shifting of the tax burden. As such, it is proposed that the PGE emission tax rate should be lower than the Pigouvian tax rate, which equals the MSC inflicted by the polluter on third parties. In terms of policy-relevant assessments, particularly considering the current trend of expanding environmental taxation in the European Union, we conclude that a tax on PGE emissions could represent an additional fiscal instrument aimed at improving environmental protection and increasing overall wellbeing.

1. König, H. P., Hertel, R. F., Koch, W. and Rosner, G., Determination of platinum emissions from a three-way catalyst-equipped gasoline-engine. Atmos. Environ. A, 1992, 26, 741-745.

2. Ravindra, K., Bencs, L. and Van Grieken, R., Platinum group elements in the environment and their health risk. Sci. Total Environ., 2004, 318, 1-43.

3. Bocca, B., Petrucci, F., Alimonti, A. and Caroli, S., Traffic-related platinum and rhodium concentrations in the atmosphere of Rome. J. Environ. Monit., 2003, 5, 563-568.

4. Schafer, J. and Puchelt, H., Platinum-group-metals (PGM) emitted from automobile catalytic converters and their distribution in roadside soils. J. Geochem. Explor., 1998, 64, 307-314.

5. Gomez, B. et al., Levels and risk assessment for humans and ecosystems of platinum-group elements in the airborne particles and road dust of some European cities. Sci. Total Environ., 2002, 299, $1-19$.

6. Moldovan, M., Gomez, M. M. and Palacios, M. A., On-line preconcentration of palladium on alumina microcolumns and determination in urban waters by inductively coupled plasma mass spectrometry. Anal. Chim. Acta, 2003, 478, 209-217.

7. Morton, O., Puchelt, H., Hernandez, E. and Lounejeva, E., Trafficrelated platinum group elements (PGE) in soils from Mexico City. J. Geochem. Explor., 2001, 72, 223-227.

8. Barbante, C. et al., Greenland snow evidence of large scale atmospheric contamination for platinum, palladium, and rhodium. Environ. Sci. Technol., 2001, 35, 835-839.

9. Moldovan, M., Origin and fate of platinum group elements in the environment. Anal. Bioanal. Chem., 2007, 388, 537-540.

10. Dubiella-Jackowska, A., Polkowska, Z. and Namiesnik, J., Platinum group elements: a challenge for environmental analytics. Pol. J. Environ. Stud., 2007, 16, 329-345.

11. Lenz, K. et al., Presence of cancerostatic platinum compounds in hospital wastewater and possible elimination by adsorption to activated sludge. Sci. Total Environ., 2005, 345, 141-152.

12. Kummerer, K., Helmers, E., Hubner, P., Mascart, G., Milandri, M., Reinthaler, F. and Zwakenberg, M., European hospitals as a source for platinum in the environment in comparison with other sources. Sci. Total Environ., 1999, 225, 155-165.

13. Artelt, S., Kock, H., Konig, H. P., Levsen, K. and Rosner, G., Engine dynamometer experiments: platinum emissions from differently aged three-way catalytic converters. Atmos. Environ., 1999, 33, 3559-3567.

14. Moldovan, M., Gomez, M. M. and Palacios, M. A., Determination of platinum, rhodium and palladium in car exhaust fumes. J. Anal. At. Spectrom., 1999, 14, 1163-1169.

15. Konieczny, P. et al., Effects triggered by platinum nanoparticles on primary keratinocytes. Int. J. Nanomed., 2013, 8, 3963-3975.

16. Rojas, F. S., Ojeda, C. B. and Pavon, J. M. C., Automated on-line separation preconcentration system for palladium determination by graphite furnace atomic absorption spectrometry and its application to palladium determination in environmental and food samples. Talanta, 2006, 70, 979-983.
17. Hees, T. et al., Distribution of platinum group elements (PT, PD, $\mathrm{RH})$ in environmental and clinical matrices: composition, analytical techniques and scientific outlook - status report. Environ. Sci. Pollut. Res., 1998, 5, 105-111.

18. Stejskal, K., Diopan, V., Adam, V., Beklova, M., Havel, L. and Kizek, R., Affecting of various plant models by cisplatin. Lis. Cukrov. Repar., 2007, 123, 328-329.

19. Babula, P., Adam, V., Opatrilova, R., Zehnalek, J., Havel, L. and Kizek, R., Uncommon heavy metals, metalloids and their plant toxicity: a review. Environ. Chem. Lett., 2008, 6, 189-213.

20. Supalkova, V. et al., Electroanalysis of plant thiols. Sensors, 2007, 7, 932-959.

21. Schafer, J., Hannker, D., Eckhardt, J. D. and Stuben, D., Uptake of traffic-related heavy metals and platinum group elements (PGE) by plants. Sci. Total Environ., 1998, 215, 59-67.

22. Rabik, C. A. and Dolan, M. E., Molecular mechanisms of resistance and toxicity associated with platinating agents. Cancer Treat. Rev., 2007, 33, 9-23.

23. Wiseman, C. L. S. and Zereini, F., Airborne particulate matter, platinum group elements and human health: a review of recent evidence. Sci. Total Environ., 2009, 407, 2493-2500.

24. Ely, J. C., Neal, C. R., Kulpa, C. F., Schneegurt, M. A., Seidler, J. A. and Jain, J. C., Implications of platinum-group element accumulation along US roads from catalytic-converter attrition. Environ. Sci. Technol., 2001, 35, 3816-3822.

25. Centemeri, L., Environmental damage as negative externality: uncertainty, moral complexity and the limits of the market. ECadernos, Centre for Social Studies, University of Coimbra, 2009.

26. Kapp, K. W., On the nature and significance of social costs. Kyklos, 1969, 22, 334-347.

27. Papandreou, A., Externality, convexity and institutions. Econ. Philos., 2003, 19, 281-309.

28. Galbraith, J. K., The Affluent Society, New American Library, New York, USA, 1958, pp. 200-250.

29. Cheung, S., The Myth of Social Cost, The Institute of Economic Affairs, London, UK, 1978.

30. Hardin, G., The tragedy of the commons. Am. Assoc. Adv. Sci., 1968, 162, 1243-1248.

31. Pigou, C. A., The Economics of Welfare, Macmillan and Co, Ltd, London, UK, 1928.

32. Sandmo, A., Optimal taxation in the presence of externalities. Swed. J. Econ., 1975, 14, 86-98.

33. Meade, J. E., External economies and diseconomies in a competitive situation. Econ. J., 1952, 62, 54-67.

34. Bovenberg, A. L. and Goulder, L. H., Optimal environmental taxation in the presence of other taxes: general-equilibrium analyses. Am. Econ. Rev., 1996, 86, 985-1000.

35. Cremer, H., Gahvari, F. and Ladoux, N., Externalities and optimal taxation. J. Public Econ., 1998, 70, 343-364.

36. Oates, W. E., Green taxes: Can we protect the environment and improve the tax system at the same time? South. Econ. J., 1995, 5, 915-922.

37. Jaeger, W., The Welfare Effects of Environmental Taxation, Environmental and Resource Economics, Springer Science, 2011.

38. Christiansen, V. and Smith, S., Emissions taxes and abatement regulation under uncertainty. Environ. Resour. Econ., 2015, 60, 17-35.

39. Baumol, W. J., On taxation and the control of externalities. Am. Econ. Rev., 1972, 62, 307-322.

40. Eskeland, G. S., A presumptive Pigouvian tax: complementing regulation to mimic an emissions fee. World Bank Econ. Rev., 1994, 8, 373-394.

41. Fullerton, D. and Wolverton, A., The case for a two-part instrument: presumptive tax and environmental subsidy. Natl. Bureau Econ. Res., 1997, 5993, 1-6.

42. Bruha, J. and Scasny, M., Social and distributional aspects of environmental tax reform proposals in the Czech Republic. EAERE, 2004, 1, 1-26. 
43. Cuervo, J. and Ved, P. G., Carbon taxes: their macroeconomic effects and prospects for global adoption. A survey of the literature. Rev. Desarrollo Soc., 1999, 43, 132-171.

44. Coase, R. H., The problem of social cost. J. Law Econ., 2013, 56, $837-877$.

45. Libecap, G. D., The tragedy of the commons: property rights and markets as solutions to resource and environmental problems. Aust. J. Agric. Res. Econ., 2009, 53, 129-144.

46. Lewin, P., Pollution externalities: social cost and strict liability. Cato J., 1982, 2, 205-229.

47. Färe, R., Grosskopf, S., Lovell, C. K. and Pasurka, C., Multilateral productivity comparisons when some outputs are undesirable: a nonparametric approach. Rev. Econ. Stat., 1989, 1, 90-98.

48. Shephard, R. W., Theory of Cost and Production Functions, Princeton University Press, Princeton, New Jersey, USA, 1970.

49. Matsushita, K. and Asano, K., Reducing $\mathrm{CO}_{2}$ emissions of Japanese thermal power companies: a directional output distance function approach. Environ. Econ. Policy Stud., 2014, 16(1), 1-9.

50. Hudgins, L. B. and Primont, D., Derivative properties of directional technology distance functions. In Aggregation, Efficiency, and Measurement, Springer, Boston, MA, USA, 2007, pp. 31-43.

51. Färe, R., Grosskopf, S., Lovell, C. K. and Yaisawarng, S., Derivation of shadow prices for undesirable outputs: a distance function approach. Rev. Econ. Stat., 1993, 1, 374-380.

52. Ekins, P., Summerton, P., Thoung, C. and Lee, D., A major environmental tax reform for the UK: results for the economy, employment and the environment. Environ. Resour. Econ., 2011, 50, 447-474.

53. Jones, B., Keen, M. and Strand, J., Fiscal Implications of Climate Change, The World Bank, Washington, USA, 2012, pp. 100-150.

54. Gahvari, F., Second-best Pigouvian taxation: a clarification. Environ. Resour. Econ., 2014, 59, 525-535.

55. McAusland, C. and Najjar, N., Carbon footprint taxes. Environ. Resour. Econ., 2015, 61, 37-70.
56. Tideman, N. and Plassmann, F., Efficient bilateral taxation of externalities. Public Choice, 2017, 173, 109-130.

57. Hoffmann, F., Inderst, R. and Moslener, U., Taxing externalities under financing constraints. Econ. J., 2017, 127, 2478-2503.

58. De Borger, B. and Glazer, A., Support and opposition to a Pigouvian tax: road pricing with reference-dependent preferences. $J$. Urban Econ., 2017, 99, 31-47.

59. Matsumura, T. and Yamagishi, A., Long-run welfare effect of energy conservation regulation. Econ. Lett., 2017, 154, 64-68.

60. Lanz, B., Wurlod, J. D., Panzone, L. and Swanson, T., The behavioural effect of Pigouvian regulation: evidence from a field experiment. J. Environ. Econ. Manage., 2018, 87, 190-205.

61. Leinert, S., Daly, H., Hyde, B. and Gallachóir, B. Ó., Co-benefits? Not always: quantifying the negative effect of a $\mathrm{CO}_{2}$-reducing car taxation policy on $\mathrm{NO}_{x}$ emissions. Energ. Policy, 2013, 63, 11511159.

62. Kubatko, O. and Kubatko, O., Economic estimations of air pollution health nexus. Environ. Dev. Sustain., 2019, 21, 1507-1517.

63. Buchanan, J. M. and Stubblebine, C. W., Externality. Economica, 1962, 29, 371-384.

64. Nerudova, D. And Dobranschi, M., Double dividend hypothesis: can it be validated by carbon taxation swap with payroll taxes. Inz. Ekon., 2015, 26, 23-32.

65. Ramsey, F. P., A contribution to the theory of taxation. Econ. J., 1927, 37, 25-29.

66. Kenkel, D. S., Are alcohol tax hikes fully passed through to prices? Evidence from Alaska. Am. Econ. Rev., 2005, 95, 273277.

ACKNOWLEDGEMENT. Financial support for this research from CEITEC 2020 (LQ1601), Czech Republic is gratefully acknowledged.

Received 24 January 2018; revised accepted 16 August 2019

doi: $10.18520 / \mathrm{cs} / \mathrm{v} 117 / \mathrm{i} 10 / 1701-1709$ 